\title{
NOTE ON AN INEQUALITY OF GAUSS
}

\section{JoSiP PEČARIĆ AND KSENIJA SMOLJAK}

Abstract. In this paper a functional defined as the difference between the left-hand and the righthand side of an extension of the Gauss inequality given in [H. Alzer, On an inequality of Gauss, Rev. Mat. Complut. 4(2) (1991), 179-183.] is studied. Related analogous of the Lagrange and the Cauchy mean value theorems are obtained. Furthermore, Gauss means are generated and their monotonicity property is proven.

Mathematics subject classification (2010): Primary 26D10, Secondary 26D15.

Keywords and phrases: Gauss inequality, mean value theorems, exponential convexity, means.

\section{REFERENCES}

[1] H. Alzer, On an inequality of Gauss, Rev. Mat. Complut. 4, 2 (1991), 179-183.

[2] S. N. Bernstein, Sur les fonctions absolument monotones, Acta Math. 52 (1929), 1-66.

[3] S. Kaijser, L. Nikolova, L-E. Persson, And A. Wedestig, Hardy type inequalities via convexity, Math. Inequal. Appl. 8, 3 (2005), 403-417.

[4] K. Krulić, J. PeČArić, AND K. Smoljak, Gauss-Steffensen's means, Math. Balkanica, 24, 1-2 (2010), 177-190.

[5] D. S. Mitrinović, J. E. PeČArić And A. M. Fink, Classical and new Inequalities in analysis, Kluwer Academic Publishers, The Netherlands, 1993.

[6] D. S. Mitrinović, J. E. PeČArić, On some Inequalities for Monotone Functions, Boll. Unione. Mat. Ital. (7) 5-13 (1991), 407-416.

[7] C. Niculescu AND L.-E. Persson, Convex functions and their applications. A contemporary approach, CMC Books in Mathematics, Springer, New York, 2006.

[8] J. E. PeČarić, F. Proschan, And Y. L. Tong, Convex functions, partial orderings, and statistical applications, Academic Press, San Diego, 1992. 